\title{
企業からの メッセージ
}

\section{機械系学生へのメッセージ}

A Message for Students of Mechanical Engineering

\section{執筆者プロフィール}

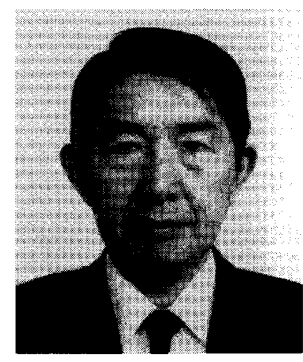

浜中 順一 Jun-ichi HAMANAKA

1940年8月生まれ

1964年東京大学工学部卒業

1966年東京大学工学系大学院修了 (工学博士)

口主として行っている業務・研究

・材料力学・計算力学

口所属学会および主な活動

日本機械学会 監事

口勤務先

石川島播磨重工業（株） 代表取締役副社長

（广100-8182 東京都千代田区大手町2-2-1 新大手町ビル／

E-mail : jyunichi_hamanaka @ihi.co.jp)

\section{1. 日本の製造業をとりまく環境の変化}

日本の製造業, 特に社会インフラや産業インフラに関わる 機械・プラントの製造業におきている主な変化を列挙すると （1）追う立場から追われる立場入；技術導入，技術提携をき つかけとした欧米技術のキャッチアップの時代は終わり，後 発国からの猛追をうけるフロントランナーになってきたこと. （2）グロ一バルな事業展開が必要：グロ一バルな市場で熾烈 なグローバル競争を勝ち抜かねばならないこと，そのために 圧倒的なコスト競争力・技術競争力, ブランド力, リスクコ ントロール能力などが必要になってきたこと.

（3）社会への責任, 地球環境への責任が重要; 企業の品格, コンプライアンスが強く問われる時代であり，企業の生産活 動が環境に与える負荷を大きく左右する時代になってきた こと.などである。

\section{2. 企業が求める若手技術者像}

従って企業が求めるこれからの技術者像は，前述のような 環境変化に敏感に対応し，自らと周りを継続的に変革してい けるマインドと能力を持った人材である，具体的には

（1）思考過程，マインド·意欲；人と同じことをするのを潔 しとせす独自性を重んじ, 多様性を許容するマインドが必要. また論理的，かつ定量的に思考し，論理的かつ定量的に人を 説得できなければならない，自らのスタンディングポイント と目標を客観的に推し量り，その差を縮めるための努力を継 続して行う意欲が重要.

（2）能力, 資質; 機械系の基盤技術（4大力学, 制御技術, 生産技術ほか）を広く修得するとともに，自分の專門分野で は誰にも負けない技術的なバックボーンを持つこと．また単 なる知識の修得のみでなく，現象の本質を深く理解する必要 がある，筆者が入社した1966（昭和41）年ころはまだ F.E.Mの創生期であり, 自分で支配方程式を变分原理などに より離散化し，アルゴリズムに苦労しながらプログラムを作 り, 解析・評価を行う必要があった。一方現在は沉用ソフト により多くの物理現象がシミュレートできるようになったた 
め，よほど努力をしないと底流を流れる一つ一つの技術に触 れることができなくなっている。

これからは1章で述べたように，技術の差別化のため，例 えば新しい理学の成果を積極的に製品に取り込むなどの努力 が必要になってくる．そのためには専門以外の分野，先端的 な技術分野にも果敢に挑戦していく意欲が重要である。

また变化の激しい時代だからこそ将来の方向と戦略を正し く選択しなければならない，そのためには広く社会や自然科 学以外の分野にも興味を持ち, 市場動向・技術の潮流を把握 する能力を養う必要がある．さらにはグローバルに活動する 機会が増すため, 異文化の理解, 語学力の研鑚などを急って はならない.

企業の活動は社員一人一人の活動の総和である．従つて企 業が品格を保つためには，社員が技術者として，何よりも 社会人，一人の人間として正しい倫理観を持つことが肝要 である.

\section{3. 学生時代に身に付けてほしいこと}

私どもの会社が研究センターを開設するため北京の清華大 学を訪れたことがある，その際技術的な議論をしているとき の学生のきらきらした目が印象的であった．また当社ではフ ランスのリヨン工科大学から学部の学生をインターンシップ として3箇月程度受け入れている. 彼らは与えられたテーマ を3箇月でまとめ，その研究成果を皆の前で発表し帰ってい く. 彼らを見ていて感じることは, (1) 数学のレベルが高いこ と, (2)与えられた問題をモデル化，定式化し解析解または数 值解析で解を得，本質的な知見を導く訓練をうけていること， (3) 人前で成果を論理的にプレゼンテーションできること，な どである.このように他国の学生が緊張感をもって日々努力 していることにわれわれは㯲を正さなければならない.

いずれにしても機械系学生諸君に大学で身につけてほしい 事柄は，(1) 数学, 力学をはじめとする幅広い基礎学力, 基 礎知識の修得，(2) 卒業論文，修士論文をまとめ学会などで 発表することによる専門分野の深化とプレゼンテーション能 力の向上, (3) 自分の考えを伝え，他人の意見を聞くコミュ ニケーション能力の向上, などである.

自分の専門分野を深めたり，新しい分野の知識を修得する ためには多くの專門書を読破する必要がある，そのとき筆者 の経験ではその分野の真の碩等の書かれた良書を選ぶことが 重要である．真にその分野を極めた碩学の書かれた専門書は いかに難しい内容であり, 難しい数式が多用されていてもそ の内容が素直に読者の頭に入ってくる．筆者が経験した例を 二, 三紹介すると「ゴールドシュタイン著; 古典力学」、「吉 村慶丸；塑性力学」「「村外志夫：マイクロメカニクス」など である.これらはいずれも高次のテンソルを用い数理的に複 雑な記述が多いが，あまり抵抗なくその内容を理解できる名 著である.

\section{4. おわりに}

もちろんライフサイエンス，情報科学などの先端技術は日 本にとって重要である.しかしこれらの先端技術は学習され やすく中抜きで後発国にも容易にキャッチアップされやす い. 一方機械工学を中心とした製造業の基盤技術は，社会イ ンフラ，産業インフラを支えるたいせつな技術であり，その 集積と高度化は容易にキャッチアップされるものではない． いかなる道を進もうとも学生諸君は高い目標を掲げそれに向 かって造進して欲しい。 